Інноватика у вихованні. Випуск 12. 2020.

УДК 37(091)(477)(092):37.011.3-051

DOI: $\underline{10.35619 / \text { iiu.v1i12.290 }}$

Сорочинська Тетяна

кандидат педагогічних наук, старший викладач кафедри філософії Рівненського державного гуманітарного університету,

м. Рівне, Україна

ORCID:0000-0002-0912-8663

e-mail: olyasorochinska7@gmail.com

\title{
ТВОРЧА СПАДЩИНА В. О. СУХОМЛИНСЬКОГО В СИСТЕМІ ПРОФЕСІЙНОӤ ПІДГОТОВКИ ВЧИТЕЛЯ
}

\begin{abstract}
Анотація. У статті розглядаються творчі напрацювання Василя Олександровича Сухомлинського щодо становлення й професійного зростання учителя, які є надважливими в сучасних умовах реформування професійної підготовки фахівця. Зокрема, здійснено обгрунтування ідеї самовиховання як необхідної передумови набуття i збереження професіоналізму вчителя; розглянуто основні характеристики педагога-початківця та педагога-майстра; як майбутній учитель 3 об’єкта виховного впливу («Я - студент, нехай мене вчать») має перетворитися на суб'єкт організації власної життєдіяльності («Я майбутній педагог, готую себе до педагогічної діяльності щоденно»). Водночас, використовуючи педагогічний досвід відомого ученого, розкрито сутність професійної індивідуальності вчителя; педагогічної культури та педагогічної техніки як вирішальних елементів формування педагогічної майстерності. Доведено, що індивідуальна педагогічна культура виявляється у професійній поведінці педагога. Здійснено порівняльний аналіз учителя з високим і низьким рівнем педагогічної культури, обгрунтовано поняття «педагогічного безкультур'я» як неуцтва та обмеженості вчителя. Зосереджено увагу на духовно-моральній складовій як основі педагогічної діяльності майбутнього фахівця.
\end{abstract}

Ключові слова: В. Сухомлинський, самовиховання, індивідуальна педагогічна культура, педагогічна техніка, професійна майстерність, педагогічний досвід.

Постановка проблеми. Кожен історично визначений час залишає після себе характерне для нього розуміння ідеалу вчителя - особистості, яка не тільки володіє системою знань, що є адекватною в науковій картині світу певного періоду, але й власною системою цінностей, самостійністю у думках та вчинках. Людини, яка $є$ відкритою до діалогу і творення культури шляхом діалогічного спілкування, обміну смислами культурного саморозвитку. Та не залежно від конкретних історичних умов епохи, людина, яка обрала професію учителя, має бути наділена певними особливими якостями та властивостями, що характеризуватимуть іï як авторитетну суспільну особистість. 3 огляду на це розглянемо творчі здобутки В.О. Сухомлинського, що увійшли в історію вітчизняної педагогічної науки і вже багато років залишаються актуальними для становлення й професійного зростання вчителя. 
Аналіз останніх досліджень 3 проблеми. Грунтовний аналіз новаторських ідей і положень В. О. Сухомлинського здійснили вітчизняні та зарубіжні вчені I. Бех, А. Богуш, М. Богуславський, А. Борисовський, М. Вашуленко, Г. Волков, I. Дереза, О. Дубасенюк, С. Слканов, І. Зязюн, В. Кузь, М. Морозова, М. Мухін, О. Остапчук, В. Риндак, О. Савченко, О. Сухомлинська, В. Федяєва та ін. Різні аспекти професійного становлення і саморозвитку вчителя, формування його педагогічної майстерності, вдосконалення технологій навчання майбутнього фахівця в творчій спадщині Василя Олександровича були в полі зору М. Антонця, С. Білецької, Л. Бондар, В. Бутенка, В. Василенко, Н. Василенко, М. Костенко, А. Луцюка, А. Розенберга, Л. Сіднєва, М. Сметанського, О. Химченко, К. Юр'євої та ін.

Метою статті $\epsilon$ аналіз творчого використання педагогічних концепцій В. О. Сухомлинського у сучасній теорії і практиці підготовки вчителя.

Виклад основного матеріалу дослідження. У нових реаліях суспільного розвитку досвід педагогічної діяльності відомого українського педагога постає надважливим аспектом у контексті реформування шкільної та професійної педагогічної освіти. Адже сучасний рівень усвідомлення школи та учня потребує реальних підходів до розуміння суті професійної індивідуальності вчителя, психолого-педагогічних умов іiі становлення. Кожен учитель має усвідомлювати свою особистісну і професійну сутність, місце і призначення у навчальному закладі, що розвивається, готовність до безперервного професійного самовдосконалення. Учитель повинен осмислювати зміст і значення моральних вимог суспільства, самостійно оцінювати власні вчинки і дії вихованців, розуміти, що таке обов'язок, відповідальність, совість, гідність, мати тверді переконання щодо самооцінки і самовиховання. Саме в цьому контексті, В. О. Сухомлинський стверджував, що самовиховання як необхідна передумова набуття і збереження професіоналізму вчителя - це систематична і свідома діяльність людини, спрямована на вироблення в собі бажаних фізичних, розумових, моральних, естетичних якостей, позитивних рис, волі і характеру, усунення негативних звичок. Це формування людиною своєї особистості відповідно до свідомо поставленої мети (Сухомлинський, 1977). Майбутній учитель 3 об'єкта виховного впливу («Я - студент, нехай мене вчать») повинен перетворитися на суб’єкт організації власної життєдіяльності («Я - майбутній педагог, готую себе до педагогічної діяльності щоденно»).

Загальновідомо, що педагог, який робить перші кроки у навчальновиховному процесі - це педагог-початківець. Він має достатню теоретичну підготовку, вміє планувати щоденну і перспективну роботу, має сформовані вміння проводити уроки, виховні заходи. Майстром будуть вважати педагога лише тоді, якщо він володіє професійними секретами: умінням сформувати у кожного учня активного суб'єкта навчально-виховного процесу; здатністю забезпечити оптимальний варіант навчання, виховання i розвитку кожної дитини; варіативним підходом до визначення теми, мети, завдань, типу уроку; корекцією діяльності кожного учня та іiі спрямуванням на пошук знань i досягнення повсякденного успіху; інструментарієм - знайти, підтримати, розвинути людину в людині, закласти в неї механізм самореалізації; високою культурою праці; наявністю взаємодії, емоційно-інтелектуальної спільності «педагог-учень»; творчим самопочуттям учителя і учня під час роботи на уроці, відчуттям задоволення від спільної праці (Зязюн, Крамущенко, Кривонос, 1997, c. 36-37). 
Отже, робота над собою - це обов'язкова передумова набуття і збереження професіоналізму вчителя. Для саморозвитку В. О. Сухомлинський рекомендував учителям «...створювати власну бібліотеку, щомісяця купувати книжки (3 проблем науки, основи якої ви викладаєте; про життя і боротьбу людей, образи яких є прикладом для молоді; про душу людини - особливо дитини, підлітка)» (Сухомлинський, 1976, с. 420).

До особи вчителя відомий педагог висував підвищені вимоги, вважаючи цю сферу особливою: «Учительська професія - це людинознавство, постійне проникнення в складний духовний світ людини, яке ніколи не припиняється. Чудова риса - постійно відкривати в людині щось нове, дивуватися новому, бачити людину в процесі іiі становлення - один із тих коренів, які живлять покликання до педагогічної праці» (Сухомлинський, 1976, с. 421). Тому, «дуже важливо, щоб з дитинства в людини було життя в світі моральних цінностей» (Омельчук, 2013, с. 28-30).

Учитель має бути людиною, яка сповідує цінності істини, розуму i розширення людських можливостей, він покликаний не тільки прищеплювати моральність, а й привчати міркувати про проблеми моралі. Василь Сухомлинський закликав: «Живи так, щоб твоя серцевина була здоровою, чистою і сильною. Бути справжньою людиною - це значить віддавати сили своєї душі в ім'я того, щоб люди навколо тебе були красивішими, духовно багатшими, щоб у кожній людині, з якою ти зустрічаєшся в житті, залишилось щось хороше від тебе, від твоєї душі» (Голік, 2010, с. 21-22).

Вирішальним елементом формування педагогічної майстерності вчителя $\epsilon$ педагогічна культура та педагогічна техніка як форми організації його поведінки. Педагогічна техніка - це вміння використовувати психофізичний апарат як інструмент виховного впливу. А також це прийоми володіння собою (своїм організмом, настроєм, мовленням, увагою, уявою) і прийоми впливу на інших. Основою педагогічної техніки вчителя $\epsilon$ педагогічна культура - сутнісна характеристика, що відображає динамічну систему його професійних цінностей діяльності та поведінки. Це інтегральна якість особистості вчителя, мірило й спосіб набуття культуротворчого досвіду людства та розвиток його в процесі професійної діяльності. Вона $\epsilon$ синтезом високого професіоналізму та особистісних якостей педагога (Зязюн, Крамущенко, Кривонос, 1997, с.37).

Індивідуальна педагогічна культура вчителя проявляється у професійній поведінці. Учителеві 3 високим рівнем педагогічної культури властиві теоретичне обгрунтування власної педагогічної позиції, системність педагогічної діяльності, творення, гнучкість і варіативність у прийнятті рішень. Такий педагог має індивідуальний стиль. Він не тільки зберігає і відтворює духовні цінності освіти й виховання, а й сам створює їх у нових технологіях, методиках, дидактичних і виховних системах. I навпаки, в учителя з низьким рівнем професійної культури очевидними $є$ невпевненість, нестійкість власної педагогічної позиції, безсистемність, непослідовність, невміння вирішувати педагогічні проблеми.

Закономірним є те, що діти навчаються в того, кого люблять і поважають. Отож, любов до дитини - «вершина педагогічної культури вчителя, думок і почуттів» (Сухомлинський, 1976-1977, с. 299). Василь Сухомлинський неодноразово підкреслював, що «школа $\epsilon$ світом душевних людських доторкань. Відкидайте примітивні міркування про те, що, мовляв, у школі не можна «розводити ніжності» - це призведе до виховання м'якотілості, слабовілля. Все 
це не так. Різкість, грубість, «сильнодіючі», «вольові» прийоми (окрик, погроза) огрублюють людське серце, роблять його байдужим до навколишнього світу й до самого себе. А де байдужість, там немає педагогічного такту, там не може бути й справжнього людського благородства» (Сухомлинський, 1977, с.610). «Педагогічне безкультур'я, - наголошував педагог, - неуцтво, де вчитель через свою обмеженість прагне перетворити дитячу беззахисність у клітку, куди він заганяє маленьке пташеня і робить $з$ ним те, що йому заманеться. Нерозуміння дитячої беззахисності - одна з головних причин незавидного становища вчителя, який зрештою втрачає владу над дітьми - адже людину не втримаєш як пташеня в клітці» (Сухомлинський, 1976, с. 638).

Важливо, щоб у процесі педагогічної діяльності вчитель ставав автором, дослідником, користувачем і пропагандистом нових педагогічних технологій, теорій, концепцій. I якщо педагог осмислює власний досвід, оновлює його, спираючись на психолого-педагогічну науку, практику i досягнення інших освітян, аналізує істинність теорій, концепцій, вступає у пошуководослідницьку, експериментальну роботу, тоді його вважають педагогом передового педагогічного досвіду. Василь Сухомлинський зауважував, що впровадження досвіду - це тонка і копітка справа, оскільки вона носить творчий характер. Адже досвід не можна передати, якщо свідомістю того, хто хоче його запозичити, не оволодіє ідея, яка стала джерелом натхнення для творчої праці (Сухомлинський, 2003, с. 692-693).

Тому для досягнення бажаного педагогічного ідеалу важливим є досвід підгрунтя, на якому зростає педагогічна майстерність учителя. Він $є$ важливим елементом загальної культури, в якій відображаються індивідуальні риси особистості педагога, що постійно розвиваються, збагачуються впродовж усієї педагогічної діяльності. Педагогічний досвід - це система педагогічних знань, умінь і навичок, способів здійснення творчої педагогічної діяльності, емоційноціннісних ставлень, здобутих у процесі практичної навчально-виховної роботи.

Висновки і перспективи подальших розвідок. Означені педагогічні концепції В. О. Сухомлинського допомагають глибше осягнути сутність професійної майстерності майбутнього фахівця; дають розуміння того, що майбутній учитель має постійно збагачувати і підвищувати свій освітній потенціал, переймаючись рівнем та якістю власної освіти; має володіти індивідуальними здібностями, які сприятимуть формуванню особистісно значущих цінностей, світогляду та компетенцій, достатнім життєвим i педагогічним досвідом. Це має бути фахівець, який вирізняється творчим i відповідальним ставленням до справи, прагненням до освіти упродовж життя і самовдосконалення. Тільки такий педагог здатен до змін та впровадження освітніх інновацій, що дозволять вирішити як проблеми сьогодення, так i запобігти виникненню подібних проблем у майбутньому.

Перспективи подальших наукових розвідок ми вбачаємо в необхідності удосконалення існуючої системи професійної підготовки вчителя відповідно до сучасних освітніх вимог та з урахуванням здобутків і досвіду минулих епох.

\section{СПИСОК ВИКОРИСТАНИХ ДЖЕРЕЛ}

Сухомлинський, В. (1977). Вибрані твори: в 5-ти томах. Київ: Рад. школа. $654 \mathrm{c}$.

Зязюн, Л., Крамущенко, І., Кривонос та ін. (1997). Педагогічна майстерність. Київ: Вища школа. 349 с. 
Сухомлинський, В. (1976). Сто порад учителеві. Київ: Рад. Школа. Т.2. С. 419-654.

Омельчук, В. (2013). Педагогіка В. Сухомлинського - педагогіка гуманізму. Кандидат педагогічних наук. Національний педагогічний університет імені М. П. Драгоманова.

Голік, О. (2010). Педагогічна майстерність: організаційно-управлінський аспект: Донецьк : Ноулідж. 2010. с. 242.

Сухомлинський, В. (1976-1977). Як виховати справжню людину. Київ: Рад. школа. Т.2. С. 149-416.

Сухомлинський, В. (2003). Розмова із молодим директором. К.С. 692-693.

\title{
REFERENCES
}

Sukhomlynskyi, V. (1977). Vybrani tvory: v 5-ty tomakh [Selected works: in 5 volumes]. Kyiv: Rad. shkola. 654 s. [in Ukrainian]

Ziaziun, L., Kramushchenko, I., Kryvonos ta in. (1997). Pedahohichna maisternist [Pedagogical skills ]. Kyiv: Vyshcha shkola. 349 s. [in Ukrainian]

Sukhomlynskyi, V. (1976). Sto porad uchytelevi [One hundred tips for teachers]. Kyiv : Rad. Shkola. T.2. S. 419-654. [in Ukrainian]

Omelchuk, V. (2013). Pedahohika V. Sukhomlynskoho - pedahohika humanizmu [V. Sukhomlynsky's pedagogy is the pedagogy of humanism] Kandydat pedahohichnykh nauk. Natsionalnyi pedahohichnyi universytet imeni M. P. Drahomanova. [in Ukrainian]

Holik, O. (2010). Pedahohichna maisternist: orhanizatsiino-upravlinskyi aspekt: [Pedagogical skills: organizational and managerial aspect] Donetsk: Noulidzh. 2010. s. 242. [in Ukrainian]

Sukhomlynskyi, V. (1976-1977). Yak vykhovaty spravzhniu liudynu [How to bring up a real person]. Kyiv : Rad. shkola. T.2. S. 149-416. [in Ukrainian]

Sukhomlynskyi, V. (2003). Rozmova iz molodym dyrektorom. [Talk to a young director] K.S. 692-693. [in Ukrainian]

\section{SUKHOMLINSKY'S CREATIVE HERITAGE IN THE SYSTEM OF TEACHER PROFESSIONAL TRAINING}

\author{
Tatiana Sorochynska \\ Candidate of Pedagogical Sciences, \\ Senior lecturer at the Department of Philosophy, \\ Rivne State University for the Humanities \\ Rivne, Ukraine \\ ORCID: 0000-0002-0912-8663 \\ e-mail:olyasorochinska7@gmail.com
}

\begin{abstract}
The article deals with the creative ideas of Vasyl Oleksandrovych Sukhomlynskyi in terms of the formation and professional growth of teachers, which are important in today's conditions of reforming the professional training of specialists. In particular, a creative analysis of the idea of self-education as a necessary prerequisite for the acquisition and preservation of teacher professionalism. The main characteristics of a novice teacher and a master teacher are considered; as a future teacher from the object of educational influence ("I am a student, let me be taught") should become a subject of organization of their own lives ("I am a future teacher, I
\end{abstract}


prepare myself for teaching every day"). The concept of the famous scientist "The teaching profession - the study of man" is also covered, in which the teacher proved that discovering something new in a person, seeing a person in the process of his formation - is one of the roots that nourish the vocation to teaching.

Using the pedagogical experience of Vasyl Sukhomlynsky, the article reveals the essence of a teacher's professional individuality; pedagogical culture and pedagogical techniques as crucial elements in the formation of pedagogical skills. It was proved that the individual pedagogical culture is manifested in the professional behavior of the teacher. The comparative analysis of the teacher with a high and low level of pedagogical culture was carried out, the concept of "pedagogical lack of culture" as incompetence and limitations of the teacher was substantiated.The focus is on the spiritual and moral component as the basis of pedagogical activity of the teacher. It is proved that in the process of professional development of a teacher it is important to study and implement the best examples of pedagogical experience.

Key words: V. Sukhomlinskyi, professional individuality of a teacher, pedagogical culture, pedagogical technique, advanced pedagogical experience.

Стаття надійшла до редакиії 20.09.2020 